\title{
The role of stents in the treatment of Crohn's disease strictures
}

Authors

Institution
Carme Loras Alastruey, Xavier Andújar Murcia, Maria Esteve Comas

Department of Gastroenterology, Hospital Universitari Mútua de Terrassa, Fundació per la Recerca Mútua de Terrassa, Terrassa, Catalonia, Spain. Centro de Investigación Biomédica en Red de Enfermedades Hepáticas y Digestivas (CIBEREHD). submitted

18. September 2015 accepted after revision 4. January 2016

\section{Bibliography}

DOI http://dx.doi.org/ 10.1055/s-0042-101786 Endoscopy International Open 2016; 04: E301-E308

(c) Georg Thieme Verlag KG Stuttgart . New York E-ISSN 2196-9736

\section{Corresponding author} Carme Loras Alastruey, MD, PhD

Department of

Gastroenterology, Endoscopy Unit

Hospital Universitari Mútua de Terrassa

Universitat de Barcelona Plaça Dr Robert no 5 08221 Terrassa, Barcelona Catalonia, Spain. Fax: +34-93-7365043 cloras@mutuaterrassa.cat cloras76@hotmail.com
Background and aims: Stenosis is one of the most frequent local complications in Crohn's disease (CD). Surgery is not the ideal treatment because of the high rate of postoperative recurrence. Endoscopic balloon dilation (EBD) currently is the current treatment of choice for short strictures amenable to the procedure. However, it is not applicable or effective in all the cases, and it is not without related complications.

Our goal was to summarize the published information regarding the use and the role of the stents in the treatment of CD stricture. A Medline search was performed on the terms "stricture," "stenosis," "stent" and "Crohn's disease."

Results: a total of 19 publications met our search criteria for an overall number of 65 patients. Placing a self-expanding metal stent (SEMS) may be

\section{Introduction \\ $\nabla$}

Stenosis is one of the most frequent local complications of Crohn's disease (CD), occurring in one of three patients within 10 years of diagnosis [1]. It happens as a result of chronic transmural inflammation with subsequent tissue remodeling, and mesenchymal cell hypertrophy due to hyperplasia and fibrosis. It occurs most frequently in the terminal ileum, ileocolonic anastomosis, and rectum, and is considered clinically relevant when there is a steady narrowing of the lumen with prestenotic dilatation and obstructive symptoms. More than $50 \%$ of patients who require ileal resection need a repeat operation after 15 years, and over $40 \%$ have recurrence of obstructive symptoms after 4 years, with the possibility in the long term of ending up having to undergo several surgical interventions [2]. Strictures are more common in CD than in ulcerative colitis, and they are more frequent when the disease is localized in the small intestine rather than in the colon exclusively ( $64 \%$ vs. $5 \%$, respectively). In different a safe and effective alternative to EBD and/or surgical intervention in the treatment of short stenosis in patients with $C D$. Indications are the same as those for EBD. In addition, SEMS may be useful in stenosis refractory to EBD and may be suitable in the treatment of longer or more complex strictures that cannot be treated by EBD. With the current information, it seems that the best treatment option is the placement of a fully covered stent for a mean time of 4 weeks. Regarding the use of biodegradable stents, the information is limited and showing poor results.

Conclusions: the use of stents in the treatment of strictures in CD should be taken into account either as a first endoscopic therapy or in case of EBD failure.

meta-analyses and systematic reviews of the effectiveness of strictureplasty in patients with $C D$, a $25 \%$ rate of recurrence at the site of the stenosis was reported, with a median time of 46 months, and with a considerable percentage of associated complications [3-5]. This suggests the need for conservative nonsurgical treatment; currently endoscopic balloon dilatation (EBD) is the endoscopic treatment of choice [6]. Several uncontrolled observational studies have shown that EBD in selected patients is a safe, effective alternative to surgery, with an overall success rate ranging from $44 \%$ to $58 \%$ [7-12]. Within the limitations of these various published studies, we found heterogeneity of technique, different endpoints, and small series of patients, among other characteristics. And the complications related to the EBD technique are not negligible.

It is, therefore, critical to find alternative conservative measures to avoid or delay surgery in $C D$ patients with stenosis.

The technological evolution of stents in recent years and their effectiveness in malignant steno- 

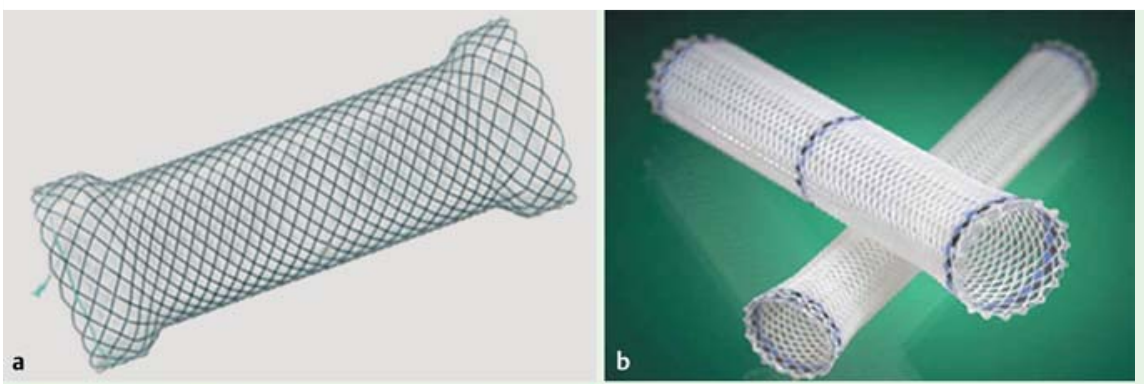

Fig. 1 Different types of stents. a self-expanding metal stent fully covered - TTS (Niti-STM - Taewoong). b Plastic stent (Polyflex ${ }^{\circledR}$ - Boston Scientific). c Self-expanding metal stent partially covered TTS (Hannaro stent ${ }^{\circledR}$ M.I.Tech). d Biodegradable stent (SX-ELLA BD stent $\left.{ }^{\circledR}\right)$
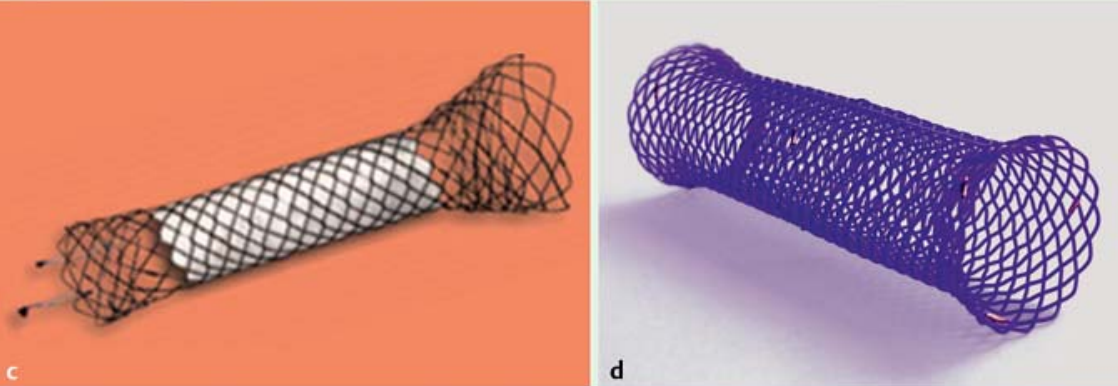

Photograph (1b) provided courtesy of Boston Scientific (@ Boston Scientific 2016. Do not copy or distribute). The content pf this publication is under the sole responsibility of its authors and does not represent the opinion of BSC. Please refer to Boston Scientific products DFUs for indications, precautions and warnings.

sis of the gastrointestinal tract has allowed their use in benign diseases of various localizations and origins, such as CD.

\section{Stent types}

Various expanding stents are commercially available (metal, plastic, and biodegradable), with differing lengths, diameters and shapes, with partial or full silicone coverage, and with differing transport and release systems, allowing placement anywhere in the upper intestinal tract, colon and even terminal ileum ( $\odot$ Fig. 1) [13-16]. Some have been designed specifically for benign intestinal stenosis and can be placed throughout the working channel (TTS: Through-the-scope stents). Until now, there has been no specific stent designed for IBD. Self-expanding metal stents (SEMS) were initially uncovered and designed for colonic malignancy as palliative treatment without the intention of removing them. Because of their efficacy in this indication, they were subsequently covered in plastic, to be removed, for use in benign intestinal pathologies. SEMS consist of metal mesh cylinders that exert self-expanding force until they reach their maximum fixed diameter. They are packaged in a compressed form and constrained on a delivery device. They are made of stainless steel and alloys such as nitinol (nickel and titanium) and elgiloy (cobalt, nickel, and chromium). The radial expandable forces and degree of shortening differ among stent types. To prevent tissue ingrowth and facilitate removal, the interstices between the metal mesh of SEMS may be fully (FCSEMS) or partially (PCSEMS) covered by a plastic membrane or silicone $[14,16]$.

Tissue reactions to SEMS are well known. The stent material becomes incorporated into both the tumour and surrounding tissue by pressure necrosis. At the edge of the stent, above and below the stenosis, the stent lodges itself deep into the wall of the organ. This reaction allows anchoring of the stent and helps to prevent stent migration. With the use of a covered stent, this integration does not always occur and a higher rate of stent migration is seen. Therefore, partially covered stents have been developed with flared uncovered segments at both ends to anchor in the tissue.
Regarding biodegradable stents, they are made of polydioxanone and are spontaneously degraded in 10 to 12 weeks. There are no biodegradable TTS stents and they would only be considered in distal intestinal tubes such as recto-sigma. Moreover, the effect of polydioxanone degradation on the tissue of an IBD patient is unknown [17].

\section{Methods \\ $\nabla$}

A Medline search including the terms "stricture," "stenosis," "stent" and "Crohn's disease" was performed. In some cases, the patients were identified reviewing one specific paper that mentioned them. The inclusion criteria were all the patients that have been treated with a stent for a stricture in $\mathrm{CD}$. We didn't exclude any article or patient where we had found that the stent was used to treat the stenosis.

\section{Scientific evidence about self-expanding metal stents}

Information regarding the efficacy and safety of SEMS in the treatment of strictures in $C D$ is limited. The first reference in the literature to the usefulness of SEMS in CD was published as a letter to the editor of Gastrointestinal Endoscopy in 1996 [18]. The son of a gastroenterologist, whose mother suffered from CD, spent 2 weeks in a hospital in the setting of a high school independent study project, learning about expandable wire stents for the treatment of obstructive esophageal and biliary tract disease. He wondered whether this sort of stent could feasibly be placed in the intestinal tract and what complications might prevent the safe placement of such a stent.

Since 1997 a total of 12 case reports [19-27] and 4 small series of patients (ranging from 5 to 17 patients) have been published (o Table 1) [28-31].

The earliest experiences found in the literature with the use of SEMS in CD were published as case reports [19-27]. These consisted of a total of nine studies involving 12 cases and with the placement of 20 stents. It is difficult to draw conclusions regarding efficacy from these studies, given the wide heterogeneity of 
Table 1 Summary of Crohn's disease patients reported in the literature with SEMS.

\begin{tabular}{|c|c|c|c|c|c|c|c|c|}
\hline Author/Year & $\begin{array}{l}\mathrm{N}^{\circ} \text { of } \\
\text { patients }\end{array}$ & Location & Length & $\begin{array}{l}\text { Previous } \\
\text { treatment }\end{array}$ & Stent type & $\begin{array}{l}\text { Technical/Clin- } \\
\text { ical success } \\
\left(\text { rate }^{1}\right)\end{array}$ & $\begin{array}{l}\text { Durantion of } \\
\text { stenting }\end{array}$ & Outcome \\
\hline \multirow[t]{2}{*}{$\begin{array}{l}\text { Matsuhashi 1997/ } \\
2000 \text { [17] }\end{array}$} & \multirow[t]{2}{*}{2} & Colon & \multirow[t]{2}{*}{-} & EBD & $\begin{array}{l}\text { FCSEMS }(15 \times 50 \\
\mathrm{mm})\end{array}$ & Yes/Yes & $4 w(S M)$ & $\begin{array}{l}\text { Symptom free } \\
\text { at } 3 \text { years }\end{array}$ \\
\hline & & IC anastomosis & & EBD & 3 FCSEMS? & Yes/Yes & $22 \mathrm{w}(\mathrm{SM})$ & $\begin{array}{l}\text { Symptom free } \\
\text { at } 4.5 \text { years }\end{array}$ \\
\hline Whole 1998 [18] & 1 & colon & - & No & TB-UC & Yes/Yes & $3 w$ & $\mathrm{BS}^{2}$ \\
\hline \multirow[t]{2}{*}{ Suzuki 2004 [19] } & \multirow[t]{2}{*}{2} & \multirow[t]{2}{*}{ Colon } & \multirow[t]{2}{*}{-} & \multirow[t]{2}{*}{-} & UCSEMS & Yes/No & $13 w$ & $\begin{array}{l}\text { Fistula terminal } \\
\text { ileum } \rightarrow \\
\text { surgery }\end{array}$ \\
\hline & & & & & 2 UCSEMS & Yes/Yes & $104 w$ & $\begin{array}{l}\text { Recurrence } \rightarrow \\
\text { stent }\end{array}$ \\
\hline Wada 2005 [20] & 1 & Colon & - & No & UCSEMS & Yes/Yes & $139 w$ & $\begin{array}{l}\text { Perforation and } \\
\text { fistula }\end{array}$ \\
\hline $\begin{array}{l}\text { Bickston } 2005 \\
\text { [21] }\end{array}$ & 1 & Ileocecal & - & EBD & $\begin{array}{l}2 \text { UCSEMS } \\
(10 \times 60 \mathrm{~mm})\end{array}$ & Yes/Yes & $8 w$ & $\begin{array}{l}\text { Symptom free } \\
\text { at } 2 \text { months }\end{array}$ \\
\hline Dafnis 2007 [22] & 1 & Colon & $5 \mathrm{~cm}$ & No & $\begin{array}{l}4 \text { UCSEMS } \\
(22 \times 90 \mathrm{~mm})\end{array}$ & Yes/Yes & $82 w$ & $\begin{array}{l}\text { Death from } \\
\text { lung cancer }\end{array}$ \\
\hline $\begin{array}{l}\text { Martines } 2008 \\
\text { [23] }\end{array}$ & 1 & IC anastomosis & $6 \mathrm{~cm}$ & EBD & $\begin{array}{l}\text { FCSEMS }(18 / \\
24 \times 80 \mathrm{~mm})\end{array}$ & Yes/Yes & $1 \mathrm{w}$ & $\mathrm{BS}^{2}$ \\
\hline Small 2008 [24] & 1 & Rectum & - & No & $\begin{array}{l}2 \text { PCSEMS } \\
(30 \times 117-57)\end{array}$ & Yes/Yes & $1 \mathrm{w}$ & $\mathrm{BS}^{2}$ \\
\hline \multirow[t]{2}{*}{ Keranen 2010 [25] } & \multirow[t]{2}{*}{2} & \multirow[t]{2}{*}{ Anastomosis } & \multirow[t]{2}{*}{ - } & \multirow[t]{2}{*}{ No } & FCSEMS & Yes/Yes & $6 w$ & $\mathrm{BS}^{2}$ \\
\hline & & & & & UCSEMS & Yes/Yes & $221 w$ & Perforation \\
\hline Levin 2012 [26] & 5 & IC anastomosis & $<6 \mathrm{~cm}$ & $\begin{array}{l}\text { EBD } \\
\text { (2 patients) }\end{array}$ & UCSEMS & $\begin{array}{l}\text { Yes } \\
(100 \%) / \\
\text { Yes }(80 \%)\end{array}$ & $3 w-9$ years & $\begin{array}{l}\text { Symptom free } \\
\text { in } 4 / 5 \text { patients }\end{array}$ \\
\hline Attar 2012 [27] & 11 & $\begin{array}{l}\text { IC anastomosis } \\
\text { (9 patients)/ } \\
\text { Terminal ileum } \\
\text { ( } 2 \text { patients) }\end{array}$ & $1-4 \mathrm{~cm}$ & $\begin{array}{l}\text { EBD } \\
\text { (9 patients) }\end{array}$ & FCSEMS & $\begin{array}{l}\text { Yes }(90 \%) / \text { Yes } \\
(36 \%)\end{array}$ & $\begin{array}{l}1-28 \text { days ( } 8 \\
\text { stents } S M \text { ) }\end{array}$ & $\begin{array}{l}\text { Symptom free } \\
\text { in } 4 / 11 \\
\text { patients } \\
\geq 1 \text { year. } 2 \text { com- } \\
\text { plications }\end{array}$ \\
\hline Branche 2012[28] & 7 & IC anastomosis & $<5 \mathrm{~cm}$ & EBD & PCSEMS & $\begin{array}{l}\text { Yes }(100 \%) / \text { Yes } \\
(71,4 \%)\end{array}$ & $1 \mathrm{w}$ & $\begin{array}{l}\text { Symptom free } \\
\text { in } 5 / 7 \text { patients, } \\
\text { mean follow-up } \\
10 \text { months. }\end{array}$ \\
\hline Loras 2012 [29] & 17 & $\begin{array}{l}\text { IC anastomosis } \\
\text { ( } 10 \text { patients)/co- } \\
\text { lon ( } 7 \text { patients) }\end{array}$ & $<8 \mathrm{~cm}$ & $\begin{array}{l}\text { EBD (14 } \\
\text { patients) }\end{array}$ & $\begin{array}{l}\operatorname{PCSEMS~(4)/~} \\
\operatorname{FCSEMS~(21)~}\end{array}$ & $\begin{array}{l}\text { Yes }(92 \%) / \text { Yes } \\
(64.7 \%)\end{array}$ & $\begin{array}{l}\text { Mean } 28 \text { days } \\
(1-112)(13 \\
\text { stents SM) }\end{array}$ & $\begin{array}{l}\text { Symptom free } \\
\text { in } 11 / 17 \text { pa- } \\
\text { tients, mean } \\
\text { follow-up } 67 \mathrm{w} \text {. } \\
1 \text { complication. }\end{array}$ \\
\hline
\end{tabular}

Abbreviations: C, ileocolonic; EBD, endoscopic balloon dilatation; FCSEMS, fully covered self-expanding metal stent; UCSEMS, uncovered self-expanding metal stent; PCSEMS, partially covered self-expanding metal stent; TB, tracheo-bronchial; SM, spontaneous migration.

1 Rate** when is applicable.

${ }^{2} \mathrm{BS}^{*}$, bridge to surgery; $w$, weeks

patients included, the type of stents used, and the fact that in half of the cases the stent placement was a bridge therapy to surgery. In 2012, a retrospective series of five refractory ileocolonic postoperative anastomotic strictures was published [28]. In all cases uncovered SEMS were used without stent removal. The procedure was successful in four patients, two of them with longterm follow-up (one of them for 9 years). The homogeneity of patients included with the same type of stent used in a similar clinical setting (anastomosis recurrence after surgery) was probably responsible for the high rate of success.

A larger series of 11 patients with intestinal stenosis (two naïve to surgery and nine with previous ileocolonic or ileocecal resection) was published the same year; all were treated with FCSEMS [29]. The procedure was considered completely satisfactory (stent removal and disappearance of obstructive symptoms) in only one patient $(9 \%)$, but in another three cases the patients were free of symptoms for more than 1 year after the spontaneous migration of the stent. So spontaneous migration should not be considered a technique failure if a patient remains free of obstructive symptoms for a long period of time. In two cases (18 $\%$ ) major morbidity requiring urgent surgery was noted and spontaneous migration of the stent was generally the rule.

From the same group, and given the poor results related to stent migration, a further study using PCSEMS was published [30]. Seven patients with ileocolonic anastomosis $(<5 \mathrm{~cm})$ were treated with PCSEMS removed at 7 days. Some $71.4 \%$ of patients remained asymptomatic with a median follow-up of 10 months, with no cases of migration or adhesion of the stent observed.

Finally, the largest series of CD patients treated with SEMS was recently published [31]. This was a retrospective multicenter (six hospitals) Spanish cohort, in which the efficacy and safety of SEMS in the treatment of symptomatic strictures refractory to 
Table 2 Summary of Crohn's disease patients reported in the literature with biodegradable stents.

\begin{tabular}{|c|c|c|c|c|c|c|c|c|}
\hline Author/Year & $\begin{array}{l}\text { No. of } \\
\text { patients }\end{array}$ & Location & Length & $\begin{array}{l}\text { Previous } \\
\text { treatment }\end{array}$ & Stent type & $\begin{array}{l}\text { Technical/ } \\
\text { clinical } \\
\text { success (rate })\end{array}$ & $\begin{array}{l}\text { Time } \\
\text { degradation }\end{array}$ & Outcome \\
\hline $\begin{array}{l}\text { Rejchrt } 2011 \\
\text { [30] }\end{array}$ & 11 & $\begin{array}{l}\text { Small intes- } \\
\text { tine, colon, IC } \\
\text { anastomosis }\end{array}$ & $\leq 5 \mathrm{~cm}$ & $\begin{array}{l}\text { EBD } \\
\text { (7 patients) }\end{array}$ & $\begin{array}{l}\text { Polydioxanone } \\
\text { biodegradable } \\
\text { stent }\end{array}$ & $\begin{array}{l}\text { Yes }(90 \%) / \text { Yes } \\
(63 \%)\end{array}$ & 4 months & $\begin{array}{l}\text { Symptom free in } \\
6-7 / 11 \text { pa- } \\
\text { tients, median } \\
\text { follow-up } 17 \\
\text { months }\end{array}$ \\
\hline $\begin{array}{l}\text { Rodrigues } \\
2013 \text { [31] }\end{array}$ & 1 & Colon & $6 \mathrm{~cm}$ & No & $\begin{array}{l}\text { Polydioxanone } \\
\text { biodegradable } \\
\text { stent }\end{array}$ & Yes/Yes & 4 months & $\begin{array}{l}\text { Symptom free at } \\
16 \text { months }\end{array}$ \\
\hline $\begin{array}{l}\text { Karstensen } \\
2014 \text { [32] }\end{array}$ & 1 & $\begin{array}{l}\text { Small-bowel } \\
\text { stricture in the } \\
\text { ascending } \\
\text { limb of an } \\
\text { ileoanal } \\
\text { J-pouch }\end{array}$ & $12 \mathrm{~cm}$ & EBD & $\begin{array}{l}\text { Custom-made } \\
\text { biodegradable } \\
\text { polydioxanone } \\
\text { monofilament } \\
\text { stent }\end{array}$ & Yes / Yes & - & $\begin{array}{l}\text { Symptom free at } \\
3 \text { months }\end{array}$ \\
\hline
\end{tabular}

Abbreviations: IC, ileocolonic; EBD, endoscopic balloon dilatation.

${ }^{1}$ Rate* when is applicable.

medical and/or endoscopic treatment in patients with CD was evaluated. A total of 25 stents (four PCSEMS and 21 FCSEMS) were placed in 17 patients with stenosis $(<8 \mathrm{~cm})$ in the colon and ileocolonic anastomosis. Thirteen patients were operated on before the stent placement and in all but three cases previous endoscopic dilation had been unsuccessful. Clinical success (defined as remaining free of obstructive symptoms at the end of the follow-up of at least 1 year after the procedure, without major complications) was achieved in $64.7 \%$ of patients ( 11 of the 17 patients) with a mean follow-up period of 67 weeks $(11-272)$. The technical success rate for stent placement was $92 \%$ (23 of the 25 stents). In four cases (16\%) the removal of the stent was technically difficult, two of them PCSEMS (50\% of the PCSEMS) and two FCSEMS (9.5\% of the FCSEMS). In these latter cases the SEMS were maintained for 8 and 16 weeks, respectively, with this long period probably being responsible for the adherence. Only one patient had a severe complication due to proximal stent migration during insertion. Endoscopic removal was not possible due to colonic angulation, even though another stent was correctly inserted during the same procedure. Although the patient was asymptomatic, he required a programmed surgical intervention 4 months later for stent removal. Thirteen of the 25 stents (52\%) presented spontaneous distal migration, due to resolution of stenosis in the majority of cases (11 of the 13 patients, $84.6 \%$ ). This was not considered an adverse effect but rather an incident that could be treated in all patients on an outpatient basis.

\section{Scientific evidence about biodegradable stents}

Regarding the use of biodegradable stents in $C D$ patients, to date only a one small series of patients $(n=11)$ [32] and 2 case reports $[33,34]$ have been published ( 0 Table 2 ).

In reviewing the literature it seems that these devices have a low likelihood of reversing stenosis when used for other indications $[17,35,36]$. In one of the studies with a large number of patients [35] in which biodegradable stents were used to treat benign esophageal strictures, an efficacy of $45 \%$ ( 9 of 21 patients) was observed with a mean follow-up of 53 weeks (25-88). Also less than encouraging were the results obtained in the only study performed in patients with CD [32]. A total of 11 patients with short stenosis ( $\leq 50 \mathrm{~mm}$ ) at various locations (small intestine, co- lon, ileocolonic anastomosis) were included. They had one faulty insertion, three migrations (two of them in two days), and one relapse at 4 months requiring the placement of a new stent. Despite the difficulty in determining the overall efficacy of the technique from the reported data, we estimate an overall success rate of $54 \%$ to $63 \%$ with a median follow-up of 17 months (12-29 months). In addition to these results we have to take into account the technical difficulties in reaching the proximal stenosis, for which a system of introduction with an over-tube balloon for stent insertion with radiology had to be devised. Moreover, in the asymptomatic patients, a follow-up colonoscopy was not performed. As noted by the authors, it was not possible to assess the possible hyperplastic reaction of the mucosa as a secondary complication after insertion of a biodegradable stent, as reported in previous studies.

Recently, two case reports were published in which a biodegradable stent was successfully placed in CD patients. One was inserted with 16 months of follow-up in a woman with $\mathrm{CD}$ and colonic stenosis of $6 \mathrm{~cm}$ in length [33]. In the other case, a custom-made biodegradable polydioxanone monofilament stent was specially manufactured and successfully placed, with 3 months of followup, in a man with an inflamed 12-cm small-bowel stricture in the ascending limb of an ileoanal J-pouch [34].

\section{Procedure description and practical aspects}

Step 1: Before endoscopic placement of an enteral stent for the treatment of $\mathrm{CD}$ stenosis, a thorough study of the disease activity and the length and location of stenosis is in order. This requires imaging techniques to obtain a good characterization of the stenosis so as to rule out any possible associated complication. We recommend endoscopic (colonoscopy, enteroscopy) and radiological studies, preferably cross-sectional imaging techniques. Magnetic resonance imaging (MRI) enterography and computed tomography (CT) are the modalities of choice. Barium small-bowel follow through (SBFT) or enteroclysis are alternative techniques when the above are not available. The aim is to assess the anatomy, length, and number of the stenosis; the degree of obstruction; disease activity; and the presence of local complications (abscesses and fistulae). The presence of a certain degree 


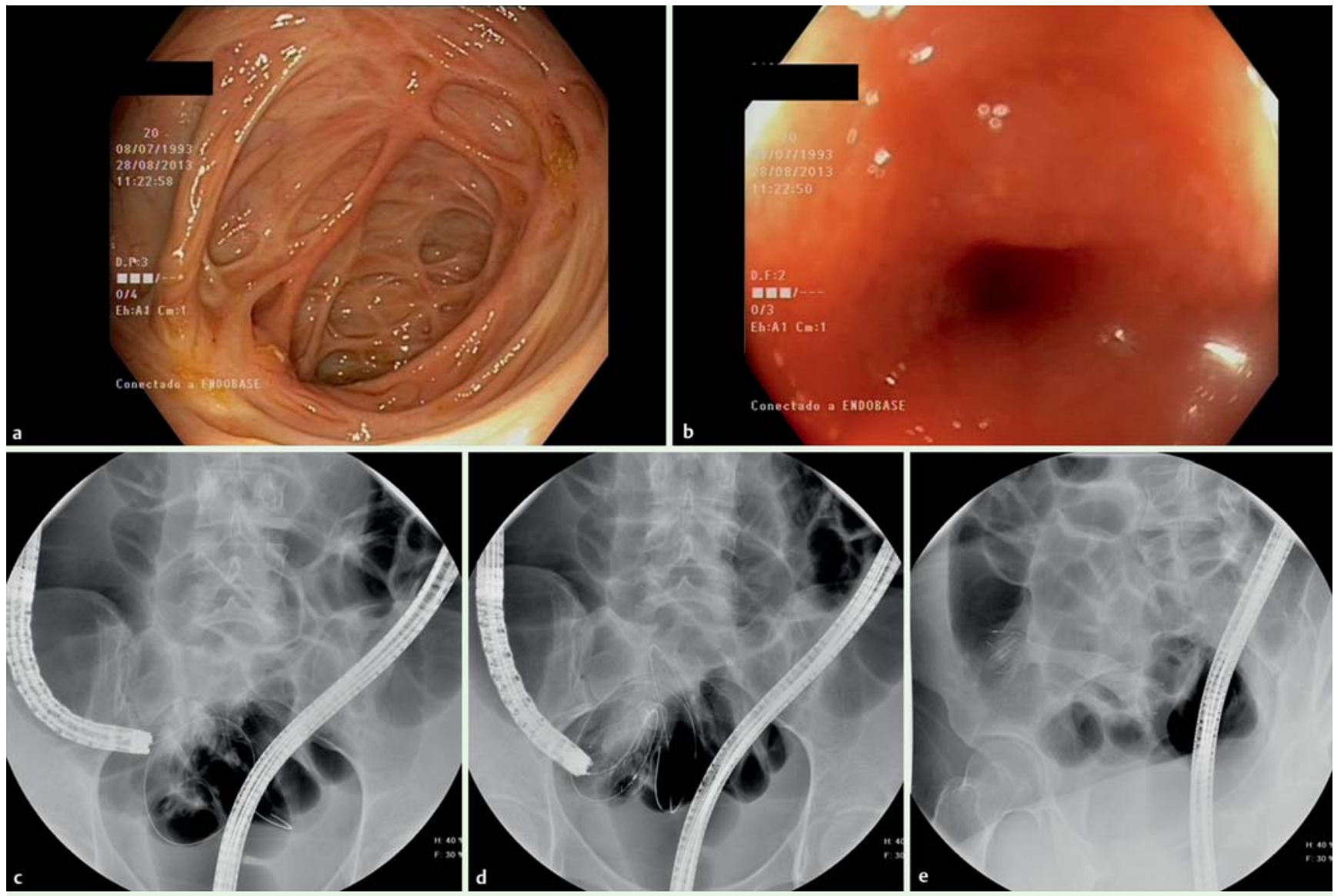

Fig. 2 Placement of an FCSEMS in stenosis of CD patient in terminal ileum. $\mathbf{a}$ and $\mathbf{b}$ Endoscopic images of the scarred cecum making it very difficult to identify the ileocecal valve and the stenosis in terminal ileum. c Passage of the guidewire through the stricture with fluoroscopic guidance. $\mathbf{d}$ and $\mathbf{e}$. Total deployment of the stent.
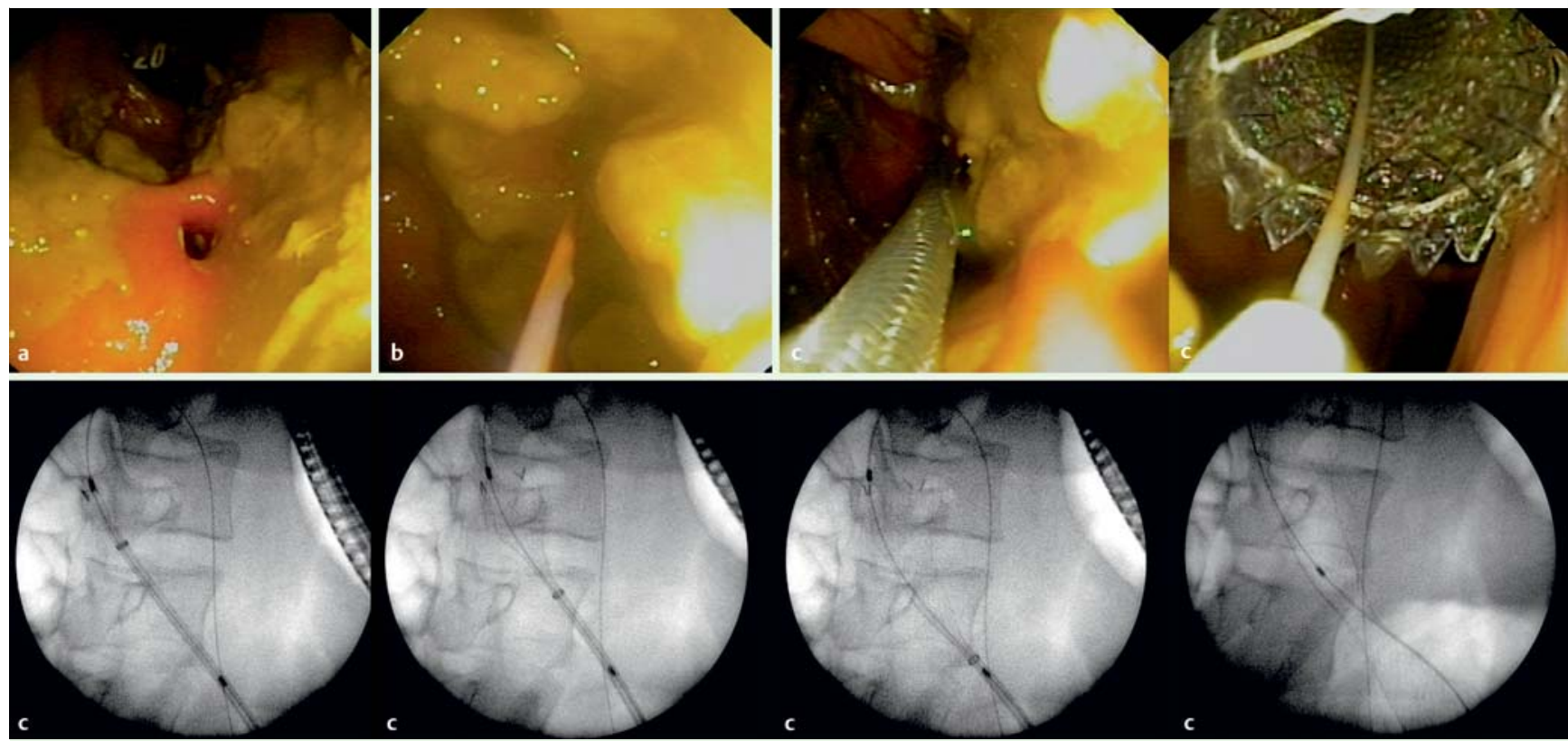

Fig. 3 Placement of FCSEMS in stenosis of ileocolonic anastomosis in CD patient. a Endoscopic image of the stenosis. $\mathbf{b}$ Passage of the guidewire through the stricture. c The whole process of stent deployment with fluoroscopic and endoscopic guidance. Image provided by Dr. Joan B Gornals, Hospital Universitari de Bellvitge. 

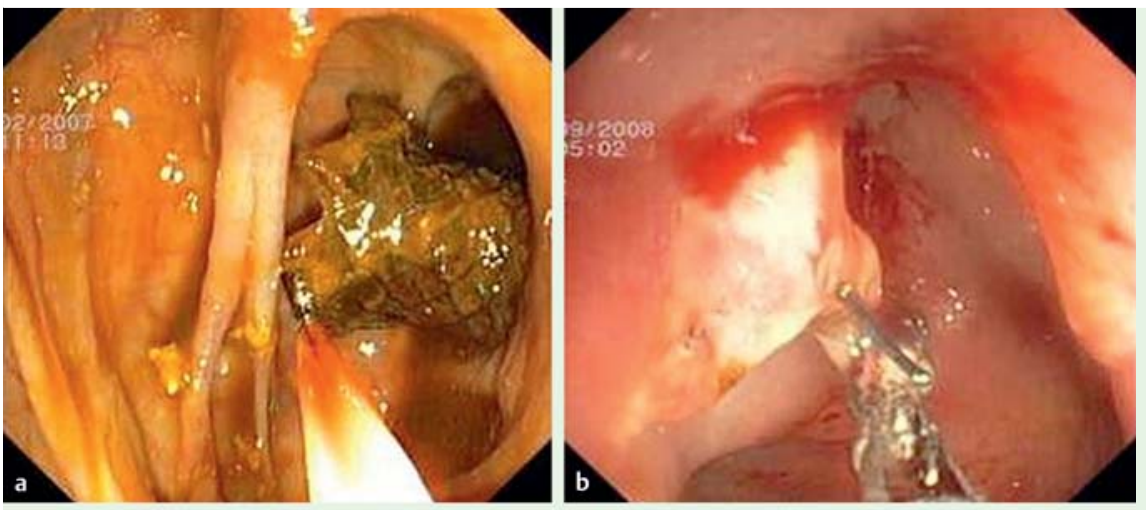

Fig. 4 Adherence of the stent in the mucosal membrane of the bowel making the removal procedure difficult. a Beginning of the removal. $\mathbf{b}$ and c Removal of the stent remains. d Post-removal of the stent.
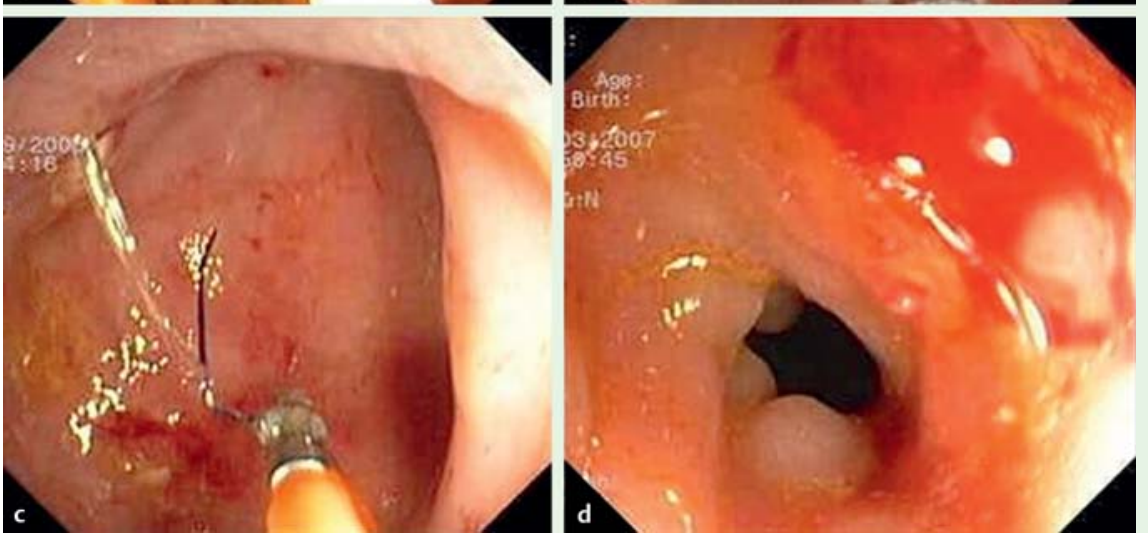

of activity does not contraindicate stent placement. By contrast, fistulae and abscesses are formal contraindications.

Step 2: The results of step 1 above allow for appropriate choice of the stent to use, above all in terms of length and diameter. The stent chosen should be at least 3 to $4 \mathrm{~cm}$ longer than the obstruction to allow an adequate margin of stent on either side of the stricture, as all stents show a degree of shortening, ranging from $5 \%$ to $40 \%$.

Step 3. During stent insertion it is preferable to perform fluoroscopy to maintain endoscopic and radiologic control at the same time. If fluoroscopy is not available, a prior dilation to ensure proper placement of the stent is recommended. However, this technique may subsequently encourage early migration of the stent.

Step 4. The endoscope must be advanced to the stenosis; after introduction of a long, soft guide-wire (usually hydrophilic biliary guide-wire), the stent can be placed. It is important to recognize the correct position of the wire passing into an air-filled distal bowel loop. Once this is done, a catheter or a Fogarty balloon can be passed over the wire. Radiographic contrast has to be injected to confirm both proper position and luminal patency before actually placing the stent. Contrast can be injected into the stent to assess complete patency ( $\bullet$ Fig. 2 and $\bullet$ Fig. 3). Optionally, clips can be positioned with or without adhesive tissue at the distal end of the stent to prevent early migration. After placing the stent, it is important not to pass through it as this maneuver could dislodge it.

Step 5. While the stent is in place, a diet with plenty of fluid intake without insoluble fiber is recommended to prevent occlusion of the device. We recommend maintaining the stent for a period not longer than 4 weeks.
Advantages and disadvantages and safety

of current stents

Advantages and disadvantages

Endoscopic treatment of a short stricture of CD can avoid or delay a surgical resection. Thus, both EBD and SEMS should be considered before surgery is undertaken. An advantage of stents is that they allow constant dilation of the lumen over a longer period of time than EBD and, at least theoretically, could be more effective. To date no comparative studies have been published to assess this possibility. However, an on-going randomized clinical trial (clinical trial NCT 02395354) will provide an answer to this question. At any rate, stent placement is an alternative to endoscopic treatment that has demonstrated efficacy in short strictures refractory to EBD. Moreover it is a feasible treatment in patients who are not candidates for EBD (those with stenosis longer than $4 \mathrm{~cm}$ or complex strictures).

The ideal type of stent is another unresolved issue, and in fact, current stents are not specifically designed for the treatment of stenosis in the CD. FCSEMS prevent adherence to mucus membrane and are thus easier to remove, but this also increases the likelihood of distal migration. By contrast, PCSEMS can prevent possible distal migration, but the increased chance of firm adherence to the mucosa makes their removal more difficult. The very limited experience with biodegradable stents does not allow a recommendation, but because their removal is unnecessary, they could theoretically have a longer effect. However, current biodegradable stents show low efficacy in other types of strictures and could produce a hyperplastic reaction in the mucosa of a patient with $\mathrm{CD}$. The technical difficulties of biodegradable stent insertion through the endoscope channel, with difficult or impossible access to proximal stenosis, makes the procedure very unattractive at present.

Endoscopic treatment of a CD stenosis with SEMS is more expensive to begin with than EBD, which is particularly true of biode- 


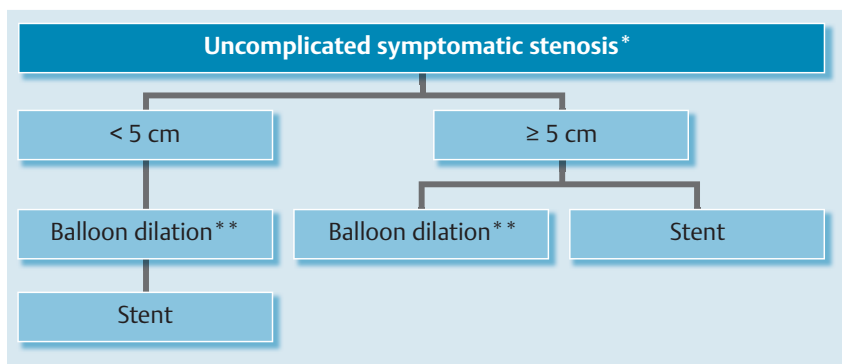

Fig. 5 Therapeutic algorithm proposed for strictures in Crohn's disease patients. ${ }^{*}$ complicated: fistula abcess; ${ }^{* *}$ optional \pm injection of substances.

gradable stents. However, a cost-benefit comparison of EBD versus SEMS has not yet been carried out. The above-mentioned trial (clinical trial NCT 02395354) should provide valuable information in this regard.

\section{Safety}

In general, placement of a stent is a safe procedure, but we have to take into account several issues associated with this technique. The first point is the difficulty of insertion. In some cases, this step can be very laborious or impossible depending on the location and angle of the stenosis. Moreover, during placement, it is imperative to be careful to avoid proximal migration of the stent [31].

The second point is the adherence of the stent to the mucus membrane of the bowel. Depending on the type of SEMS (FCSEMS or PCSEMS), it is important not to leave the stent in place for more than 4 to 6 weeks (less time for PCSEMS) to avoid complications during removal [31]. Hyperplastic mucosal reaction to a foreign body is unlikely with a shorter period of time (৫ Fig.4).

The third point is the possibility of perforation. This complication has been described mostly in malignant disease due to mucosal erosion at the ends of the stents when they are not removed [37]. In IBD patients, this complication has never been reported when the stent was used as a temporary treatment. Avoiding excessive angling of the stent and using flexible stents are two measures that help minimize risk.

The last point that has to be mentioned is the frequent spontaneous distal migration of the stent $[29,31]$. Usually this occurs because the stenosis is resolved by the stent and for that reason, it is considered an incident rather than a complication. Moreover, the patient may spontaneously eject the stent, obviating the need to take it out endoscopically. Otherwise, the stent usually migrates to the rectum and may thus be easily removed with a forced biopsy.

\section{Conclusions}

For the time being, we can conclude that the use of stents is clearly indicated in refractory cases of failure of endoscopic treatment with EBD and in cases in which EBD does not eliminate the need for immediate or future surgery. Moreover, taking into account results of the largest study [31] conducted in patients at high risk of refractoriness to prior endoscopic therapy, the overall efficacy of SEMS was equal to or even greater than that reported in the literature for EBD. Thus, SEMS could also be considered an alternative endoscopic treatment to EBD in some cases. In cost-ef- fective terms, although treatment with SEMS is initially more expensive when compared with EBD, we must bear in mind that in most patients a mean of 2.2 dilations to achieve good efficiency is required. Therefore a comparative study of cost-effectiveness of the two techniques is required, considering not only the cost of the materials used, but also the overall cost of the procedures (number of admissions, complications, etc.).

At present, despite the limited information we have to date, placing a SEMS may be a safe and effective alternative to EBD and/or surgical intervention in the treatment of short stenosis in patients with $\mathrm{CD}$. It may have the same or possibly more indications than does EBD (such as longer or complex strictures). With the current information, it seems that the best treatment option may be the placement of a fully covered stent for a mean time of 4 weeks. Moreover, development of biodegradable stents in the future seems promising given the advancement in technology. We can expect that modified stents that exert greater radial strength and a TTS placement system will help improve current results.

With the currently available information, we propose a therapeutic algorithm in which stents could play a role ( $\bullet$ Fig.5). Nevertheless, well-designed prospective randomized studies on the use of stents in IBD comparing the different endoscopic techniques are required in order to establish the correctness of this algorithm.

Future development of this treatment will see improvement in the design of stents specifically adapted for IBD, biodegradable stents, and/or stents that release medication.

\section{Competing interests: None}

\section{References}

1 Cosnes J, Cattan S, Blain A et al. Long-term evolution of disease behavior of Crohn's disease. Inflamm Bowel Dis 2002; 8: 244-250

2 Rutgeerts P, Geboes K, Vantrappen G et al. Predictability of the postoperative course of Crohn's disease. Gastroenterology 1990; 99: 956-963

3 Hommes DW, van Deventer SJ. Endoscopy in inflammatory bowel diseases. Gastroenterology 2004; 126: 1561-1573

4 Tichansky D, Cagir B, Yoo E et al. Strictureplasty for Crohn's disease: meta-analysis. Dis Colon Rectum 2000; 43: 911-919

5 Wibmer AG, Kroesen AJ, Gröne J et al. Comparison of strictureplasty and endoscopic balloon dilatation for stricturing Crohn's disease-review of the literature. Int J Colorectal Dis 2010; 25: 1149-1157

6 Vrabie R, Irwin GL, Friedel D. Endoscopic management of inflammatory bowel disease strictures. World J Gastrointest Endosc 2012; 4: $500-$ 505

7 Hassan C, Zullo A, De Francesco V et al. Systematic review: Endoscopic dilatation in Crohn's disease. Aliment Pharmacol Ther 2007; 26: $1457-1464$

8 Van Assche G, Thienpont C, D'Hoore A et al. Long-term outcome of endoscopic dilatation in patients with Crohn's disease is not affected by disease activity or medical therapy. Gut 2010; 59: 320-324

9 Gustavsson A, Magnuson A, Blomberg B et al. Endoscopic dilation is an efficacious and safe treatment of intestinal strictures in Crohn's disease. Aliment Pharmacol Ther 2012; 362: 151-158

10 Bhalme M, Sarkar S, Lal S et al. Endoscopic balloon dilatation of Crohn's disease strictures: results from a large United Kingdom series. Inflamm Bowel Dis 2014; 20: 265-270

11 Hagel AF, Hahn A, Dauth W et al. Outcome and complications of endoscopic balloon dilatations in various types of ileocaecal and colonic stenosis in patients with Crohn's disease. Surg Endosc 2014; 28: 2966-2972

12 Morar PS, Faiz O, Warusavitarne J. Crohn's Stricture Study (CroSS) Group. et al. Systematic review with meta-analysis: endoscopic balloon dilatation for Crohn's disease strictures. Aliment Pharmacol Ther 2015; $42: 1137-1148$ 
13 Baron TH, Harewood GC. Enteral self-expandable stents. Gastrointest Endosc 2003; 58: $421-433$

14 Kochar R, Shah N. Enteral stents: from esophagus to colon. Gastrointest Endosc 2013; 78: 913-918

15 Gonzalez-Huix F, Abadal VillayandreJM. Materiales y tipos de prótesis de colon. En: Abadal JM. Stent de Colon. Editorial médica Panamericana, S.A. 2007: ISBN: 978-84-9835-123-1

16 Varadarajulu S, Banerjee S, Barth B. ASGE Technology Committee. et al. Enteral stents. Gastrointest Endosc 2011; 74: 455-464

17 Lorenzo-Zúñiga $V$, Moreno-de-Vega $V$, Marín I et al. Biodegradable stents in gastrointestinal endoscopy. World J Gastroenterol 2014; 20: $2212-2217$

18 Leichter J. Potential for expandable stents in Crohn's disease. Gastrointest Endosc 1996; 44: 637-638

19 Matsuhashi N, Nakajima A, Suzuki A et al. Long-term outcome of nonsurgical strictureplasty using metallic stents for intestinal strictures in Crohn's disease. Gastrointest Endosc 2000; 51: 343-345

20 Wholey MH, Levine EA, Ferral $H$ et al. Initial clinical experience with colonic stent placement. Am J Surg 1998; 175: 194-197

21 Suzuki N, Saunders BP, Thomas-Gibson S et al. Colorectal stenting for malignant and benign disease: outcomes in colorectal stenting. Dis Colon Rectum 2004; 47: 1201 - 1207

22 Wada H, Mochizuki Y, Takazoe M et al. A case of perforation and fistula formation resulting from metallic stent for sigmoid colon stricture in Crohn's disease. Tech Coloproctol 2005; 9: 53-56

23 Bickston SJ, Foley E, Lawrence C et al. Terminal ileal stricture in Crohn's disease: treatment using a metallic enteral endoprosthesis. Dis Colon Rectum 2005; 48: $1081-1085$

24 Dafnis $G$. Repeated coaxial colonic stenting in the palliative management of benign colonic obstruction. Eur J Gastroenterol Hepatol 2007; 19: $83-86$

25 Martines G, Ugenti I, Giovanni M et al. Anastomotic stricture in Crohn's disease: bridge to surgery using a metallic endoprosthesis. Inflamm Bowel Dis 2008; 14: 291 - 292

26 Small AJ, Young-Fadok TM, Baron TH. Expandable metal stent placement for benign colorectal obstruction: outcomes for 23 cases. Surg Endosc 2008; 22: 454-462
27 Keränen I, Lepistö A, Udd M et al. Outcome of patients after endoluminal stent placement for benign colorectal obstruction. Scand J Gastroenterol 2010; 45: 725 - 731

28 Levine RA, Wasvary H, Kadro $O$. Endoprosthetic management of refractory ileocolonic anastomotic strictures after resection for Crohn's disease: Report of nine-year follow-up and review of the literature. Inflamm Bowel Dis 2012; 18: 506-512

29 Attar A, Maunoury V, Vahedi K. the GETAID. et al. Safety and efficacy of extractible self-expandable metal stents in the treatment of Crohn's disease intestinal strictures: A prospective pilot study. Inflamm Bowel Dis 2012; 18: 1849-1854

30 Branche J, Attar A, Vernier-Massouille G et al. Extractible self-expandable metal stent in the treatment of Crohn's disease anastomotic strictures. Endoscopy 2012; 44: 02E325 - 326

31 Loras C, Pérez-Roldan F, Gornals JB et al. Endoscopic treatment with self-expanding metal stents for Crohn's disease strictures. Aliment Pharmacol Ther 2012; 36: 833-839

32 Rejchrt S, Kopacova M, BrozikJ et al. Biodegradable stents for the treatment of benign stenoses of the small and large intestines. Endoscopy 2011; 43: $911-917$

33 Rodrigues C, Oliveira A, Santos L et al. Biodegradable stent for the treatment of a colonic stricture in Crohn's disease. World J Gastrointest Endosc 2013; 5: 265-269

34 Karstensen JG, Vilmann P, Hendel J. Successful endoscopic treatment of a 12-cm small-bowel Crohn stricture with a custom-made biodegradable stent. Endoscopy 2014; 46: E227-228

35 Repici A, Vleggaar FP, Hassan C et al. Efficacy and safety of biodegradable stents for refractory benign esophageal strictures: the BEST (Biodegradable Esophageal Stent) study. Gastrointest Endosc 2010; 72: 927-934

36 van Hooft JE, van Berge Henegouwen MI, Rauws EA et al. Endoscopic treatment of benign anastomotic esophagogastric strictures with a biodegradable stent. Gastrointest Endosc 2011; 73: 1043 - 1047

37 van Hooft JE, van Halsema EE, Vanbiervliet G et al. Self-expandable metal stents for obstructing colonic and extracolonic cancer: European Society of Gastrointestinal Endoscopy (ESGE) Clinical Guideline. Endoscopy 2014; 46: $990-1053$ 